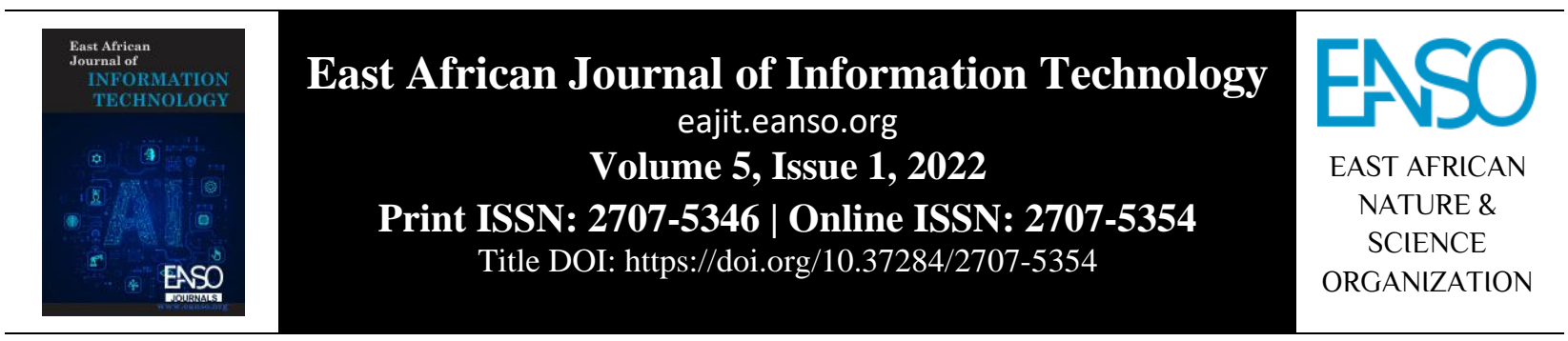

Original Article

\title{
Assessment on Public Mobile Service Delivery Towards Customer Satisfaction in Tanzania Telecommunication Industry.
}

Tina Richard Mrosso ${ }^{1} \&$ Omary Swallehe ${ }^{1 *}$

${ }^{1}$ Mzumbe University, P. O. Box 1 Mzumbe, Morogoro, Tanzania.

* Correspondence email: oswalehe@ mzumbe.ac.tz.

Article DOI: https://doi.org/10.37284/eajit.5.1.558

\section{Date Published: ABSTRACT}

21 February 2021 The paper assessed public mobile service delivery towards customer satisfaction in Tanzania telecommunication Industry. The paper focused on the

Keywords: mobile service delivery in the public entity in the Tanzanian environment. It

Public Mobile Service, was guided by three assumptions tested on customer satisfaction as the

Service Delivery,

Customer

Satisfaction, dependent variable. The assumptions consisted of the independent variables including limited network coverage, limited internet services, and limited customer response. The explanatory design was used to facilitate knowledge generation through causal relationship testing. Data for the study were

Telecommunication

Company $(s)$ assembled from customers using public mobile services with the data generated from the sample of 137 participants out of 150 as respondents using structured questionnaires. The collected information from the field was filled in SPSS datasheet to generate statistics to present the findings. The pattern of relationship testing between variables was analysed using correlation and multiple regression. Findings revealed that all three independent variables, namely limited network coverage, limited internet services, and limited customer response were found positive with a statistically significant effect on customer satisfaction $(\mathrm{p}<0.05)$ as the dependent variable. The implication of the findings is that customer satisfaction in public mobile service delivery in Tanzania is affected by limited network coverage, limited internet services, and limited customer response. The study recommended that the corporation is essential in facilitating further investment in the infrastructure facilities to assure that customers are well satisfied in service provision.

20| This work is licensed under a Creative Commons Attribution 4.0 International License. 
East African Journal of Information Technology, Volume 5 Issue 1, 2022

Article DOI: https://doi.org/10.37284/eajit.5.1.558

APA CITATION

Mrosso, T. R \& Swallehe, O. (2022). Assessment on Public Mobile Service Delivery Towards Customer Satisfaction in Tanzania Telecommunication Industry. East African Journal of Information Technology, 5(1), 20-30 https://doi.org/10.37284/eajit.5.1.558

\section{CHICAGO CITATION}

Mrosso, Tina Richard \& Omary Swallehe. 2022. "Assessment on Public Mobile Service Delivery Towards Customer Satisfaction in Tanzania Telecommunication Industry". East African Journal of Information Technology 5 (1), $20-30$. https://doi.org/10.37284/eajit.5.1.558.

\section{HARVARD CITATION}

Mrosso, T. R \& Swallehe O. (2022) “Assessment on Public Mobile Service Delivery Towards Customer Satisfaction in Tanzania Telecommunication Industry”, East African Journal of Information Technology, 5(1), pp. 20-30. doi: 10.37284/eajit.5.1.558.

\section{IEEE CITATION}

T. R. Mrosso \& O. Swallehe. "Assessment on Public Mobile Service Delivery Towards Customer Satisfaction in Tanzania Telecommunication Industry”, EAJIT, vol. 5, no. 1, pp. 20-30, Feb. 2022.

\section{MLA CITATION}

Mrosso, Tina Richard \& Omary Swallehe. "Assessment on Public Mobile Service Delivery Towards Customer Satisfaction in Tanzania Telecommunication Industry". East African Journal of Education Studies, Vol. 5, no. 1, Feb. 2022, pp. 20-30, doi:10.37284/eajit.5.1.558.

\section{INTRODUCTION}

Service delivery is the expectation by the customer(s) and or beneficiaries in the acquisition of services by the respective entity that provides the services through payment in exchange (Shanka, 2012). Also, it is the end result that is necessary to be achieved by the service provider since it has positive implications with market share generation and the attainment towards competitive advantage (Zwick et al., 2015). This is therefore an investment to the companies and or entities in pursuit of business activities with the aim to generate customers in the competitive market environment. Service delivery is embedded in different ways depending on the entity and the services that are provided such that it is applicable in organisations both public and private for the purpose of assuring adequate and effective customer service and satisfaction is realised (Ojasalo, 2010).

Service delivery is the practice that can be exercised in all forms of organisations, both formal and informal regardless of the sector provided that there are customers and or beneficiaries to be served. This is embedded in the entities operating informally that one may design a strategy that assures reliability, assurance, tangibility, empathy, and responsiveness in the process of service delivery in businesses operated under low scale and attain significant market share and competitive advantage (Swallehe, 2021). Service delivery is an important practice in business entities and public organisations in most accounts because it is the remedy towards performance attainment. After all, customers are the primary focus and concern in the success of any business (Uysal \& Mehmet, 2013).

This is attributed to the fact that businesses assure wealth generation through consumption of the services and goods provided and generated by the customers regardless of the sector and venture(s). With public organisations, service delivery is the core function and practice since they operate and execute tasks with the purpose of service delivery to the public in a manner that is affordable as possible to access as many as possible without exclusion (Ojasalo, 2010). In that case, consumption is mostly influenced by the service quality pattern and practices of the organisation to the customers and or beneficiaries (Temba, 2013). This is further attributed to the fact that service quality enables the organisation responsible to assure reliability prior to the customer service pattern and practice.

Despite that, it fosters the realisation of assurance in serving the customers, attractive observable features, and objects of the entity that may attract customers to utilise and consume the products and services offered (Zwick et al., 2015). Furthermore, service delivery assures the responsive practice of the business to the customers and empathy such that as they are well executed the results tend to be positive as far as the performance of the 
organisation is concerned. Performance of the organisation through service delivery is determined by several aspects apart from profit generation alone through wealth gathering, but also by means of customer satisfaction as well (Wolfinbarger \& Gill, 2013).

This is certain with the fact that service delivery assures customer satisfaction because they are satisfied with needs and wants being realised such that wealth generation becomes automatic (Shanka, 2012). Service delivery is embedded in the organisation in any sector including the telecommunication sector. This is due to the fact that most of them all over the globe are private entities and others operate as multinational organisations (Swallehe, 2021). Service delivery is essential in telecommunication companies since it is useful to foster sales performance which accelerates income generation through customer consumption of the products and services.

Tanzania, in particular, constitutes several telecommunication companies both public and private-owned as multinational corporations (Skinner, 2015). They include Tanzania Telecommunications Corporation which is the largest and publicly owned. Other entities operating in the area are Vodacom Tanzania, Halotel Tanzania, Airtel Tanzania, Tigo Tanzania, Zantel Tanzania, Smile, and others (Tripathy \& Goma, 2010). The companies consist of several business strategies including service deliveries to the customers to facilitate sales performance through customer awareness, customer increase, and business branding since they are useful in facilitating the satisfaction of customers.

The companies specifically consist of several distinct promotion strategies to foster individual business gains enabling adequate service delivery patterns (Smith, 2013). However, Tanzania Telecommunications Corporation in particular is a public company owned by the government of the United Republic of Tanzania such that the assumption is that a public entity seeks to provide services to the public at affordable costs (Harper, 2014). Since that is the case, it has been tasked to work as an independent agent and pay royalties to the government as a result of the earnings gathered through the communication and internet services it provides and several products and services provided to the customers for consumption (Smith, 2013). This brings the need to have adequate service delivery measures to boost its sales on the products and services to the customers to cater for satisfaction to ensure the performance of the organisation.

Since that is the case, service delivery is the core function and requirement of the organisation to ensure satisfaction while targeting as many as possible without exclusion (Tripathy, 2010). On that note, several concerns have been raised prior to the service delivery pattern that there have been outcomes which pose limited outcomes to the satisfaction of the customers such as limited internet coverage, limited network availability in conducting several activities, limited internet speed when one uses the services and several others (TGC, 2019). These are considered to be hindering concerns towards satisfaction of customers which is important to address the situation since it still persists.

This prompts the need to conduct the study since various studies have been undertaken on telecommunication companies pertaining to customer satisfaction in line with private companies' focus. This includes the study by Siria (2018) assessing the effect of corporate social responsibility on the corporate performance in telecommunication companies with reference to Vodacom Tanzania and Tigo Tanzania. Despite that, Dickson (2019) also assessed the contribution of an advertisement on customer attractions in Mic Tigo Tanzania Company Limited. Since that is the case, still little has been done on service delivery in a public telecommunication company in Tanzania which is important to address the situation.

\section{LITERATURE REVIEW}

The paper comprises mainly three components which are theoretical reviews, empirical reviews, and the description of the study variables through the conceptual model that guided the inquiry.

\section{Theoretical Reviews}

The study was guided by the SERVQUAL model propagated by Parasuraman et al. (1985) explaining the means and processes in business conduct that 
assures the capturing of consumer expectations and views prior to the business practice (Parasuraman et $a l ., 1985)$. The theory provides five main principles to be followed and adhered to in the business to enable the attainment of consumer expectations which are scientific and practical because they positively capture the reality.

The principles to have adhered which are perceived as the dimensions include first reliability which entails the capability of the business to deliver the promised services and products in the manner that assures customers to depend on the business without doubts (Parasuraman et al., 1988). This assures trust and commitment by the customers which fosters loyalty. The second principle is tangibility which is the way the physical facilities, individuals providing the services, premises of the businesses, and all other things that can be seen by naked eyes appear to the customers (Zeithaml et al., 1990).

This is an important aspect in attaining consumer expectations because the appearance in business facilities is a central component as well in assuring trust and commitment of the customers. The other dimension is responsiveness which is the willingness to help customers in providing services (Mahapatra \& Khan, 2006). This assures good relations between the business and the customers because it is easy for loyalty and affection to be built between customers and the business. The other dimension is an assurance which is the ability of the employees as service providers to demonstrate trust and confidence in serving customers (Lee, 2016).

This automatically assures customers trust and commitment because customers tend to develop trust in the service providers prior to the business practices (Higgs et al., 2005). The last dimension is empathy which is the ability of the service providers to show caring and individualised attention to the customers in accessing their needs and wants, as well as in need to be assisted in any queries (Caruanaa et al., 2000). This is important because it develops customers' commitment once it is properly done such that loyalty and trust are well established.

The theory is well related to the study because the service delivery assessment towards customer satisfaction in public telecommunication entity in developing the relations between the organisation and the customers seeks to be performed in line with the dimensions provided by the service quality model in practice on reliability, assurance, responsiveness, empathy, and tangibility. This is the goal that needs to be achieved in the new changing environment for the purpose of further advancing the organisation's interests.

Apart from that, the study was analysed further using business enterprise theory by Thorsten Veblen suggesting that any business practice is assured with growth and success provided that two components are effective in the business, which are the business and the industry (Khanna, 2013). The components connect to each other in assuring the success in the business undertaking since the business serves as the area where transactions are taking place and the wealth is generated to assure income generation and profitability which is the core expectation and result of the business (Leigh, 2011).

Despite that, the industry, on the other hand, implies the avenues where goods and or services for purchasing to take place are generated (Goldberg, 2016). These two components vary in their actual reality depending on the type of the business and the entire pattern of its operations. Since that is the case, the theory is credited to capture the reality in the business undertaking that it is certain that business activities, in reality, possess such components depending on the type and the nature of the business that is being conducted for that matter (Rowe, 2007).

The theory is well related to the study in the sense that in public telecommunication companies being the main actor are the entity that comprises the business and the industry altogether. The entity is the business since it is where transactions are done and taking place which assures income generation. Customers on the other hand serve as the industry because they originate from the public which is important for their relationship to be tested.

\section{Empirical Reviews}

Kalushekya (2017) carried out a study on assessing the effect of monitoring and evaluation on the sustainability of construction projects at Tanzania Telecommunication Company Limited (TTCL). The study has been conducted in Tanzania, specifically in Tanzania Telecommunication Company Limited (TTCL) on the construction 
projects performed by the organisation. It was conducted using explanatory study design by means of relationship testing between study variables, whereas three variables were identified to be tested sustainability of the projects which were compliance to guidelines and procedures, resource requirements and resource used; as well as time management. The results revealed that all the three variables of the study were generated positively with a significant effect on the sustainability of the projects.

The implication was that sustainability in the construction projects through monitoring and evaluation is facilitated by compliance to guidelines and procedures, resource requirements and resources used, as well as time management. This, in turn, entails the gap to be filled since few studies have been done on public service delivery and customer satisfaction in Tanzania Telecommunication Corporation which is the former Tanzania Telecommunication Company Limited (TTCL), whereas it is necessary to bridge the gap.

Bujara (2018) carried out a study assessing the influence of organisational culture on employees' performance in Tanzania Telecommunication Company Limited (TTCL). The study was conducted in Tanzania specifically in the area using a survey design using inferential analysis in establishing the causal relationship between study variables of the study. In that case, three variables were identified to be tested which were organisation mission, employee involvement, and cultural practices in the organisation.

Findings revealed that all the three variables of the study, namely organisation mission, cultural practices, and employee involvement, consist of positive effects towards employee performance using organisation culture. Since that is the case, still little has been undertaken on service delivery and customer satisfaction since the organisation is public which serves as the area useful to undertake the study venture. In that case, the study is being conducted to fill the gap in particular in Tanzania Telecommunication Corporation as the former Tanzania Telecommunication Company Limited.

Siria (2018) examined the effect of corporate social responsibility on the performance of telecommunication companies in Tanzania. The study was conducted using survey design through causality testing, whereas three variables were identified for testing, including customer increase, customer feedback, and sales generation which were tested on the performance of the companies in the country. However, the findings of the study revealed that all three predicting variables were found positive with a significant effect on the dependent variable which implies that performance in telecommunication companies through corporate social responsibility (CSR) is influenced through customer increase, feedback, and sales promotion. Regardless of that, the study further recommended that another study should be conducted on the public telecommunication companies prior to the performance in the business practice since most inquiries have focused on the private telecommunication companies. Therefore, the study was conducted specifically to address the gap respectively.

Swallehe and Mandari (2013) examined the usefulness of service quality promotion and practices on the satisfaction of customers in the library service provision at Mzumbe University and University of Dar es salaam Library services. The study employed a survey design, whereas the findings showed that service quality is an important practice in promoting the business and attracting customers, as well as assuring feedback generation to respond further to the needs and wants of the customers and general public. This has been the key concern and catalyst towards the development and growth of the Education sector in Tanzania. However, the study further recommended that another study may be conducted on the area but in another sector apart from the high education sector, telecommunication industry and others. Therefore, the study responds to the issue to address the gap.

Nyangarika (2016) assessed service delivery processes on customer satisfaction in private telecommunication companies in Tanzania. The study employed a survey design with the findings revealing that service delivery practices have been fostering good performance and response to the needs and want of the customers. This has also been facilitating competitive advantage attainment by the companies. This has been well fostered and executed by the companies to assure that they strive 
for the better to ensure they positively foster the generation of good performance for that matter. Since that is the case, the study recommended that another study should be further conducted along the same area with the focus on public telecommunication companies in Tanzania since few studies have been conducted on the area. The study may be of relevance because of corporate entrepreneurship measures undertaken by the public telecommunication company. In that case, the study is conducted to address the gap.

\section{Figure 1: Conceptual Framework}

Independent Variables

\section{Conceptual Model}

This is the model which specifically describes the study variables which depicts the pattern of relationship influence between study variables to facilitate the information generation process for that matter. In that case, the variables include independent ones and the dependent ones which are illustrated in Figure 1.

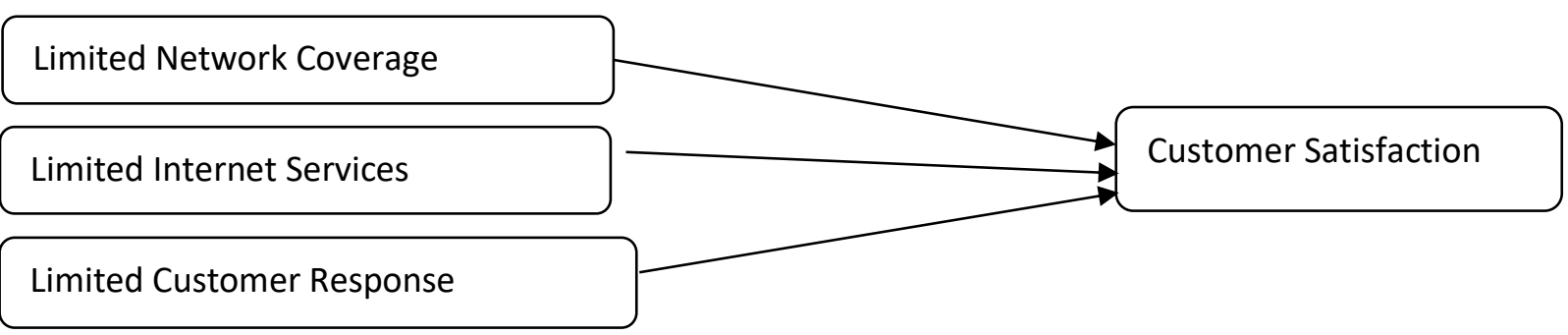

The model describes the study on assessing public mobile service delivery towards customer satisfaction in Tanzania Telecommunication Corporation. The key assumption of the study is that customer satisfaction in public telecommunication company which is Tanzania Telecommunication Corporation through service delivery is affected by different concerns. Therefore, three hypotheses have been identified stated as follows.

H1: Limited network coverage negatively affects customer satisfaction in Tanzania Telecommunications Corporation.

H2: Limited internet services negatively affect customer satisfaction in Tanzania Telecommunications Corporation.

H3: Limited customer response negatively affects customer satisfaction in Tanzania Telecommunications Corporation.

\section{METHODOLOGY}

The paper was articulated through explanatory design through causal relationship approach with the knowledge gathered through relationship testing between study variables. The results were gathered using primary data which were collected from Tanzania Telecommunication Corporation (TTCL) using the sample of 137 out of 150 respondents. Random sampling technique was used to pick respondents because participants in the study were customers using public mobile service in Tanzania. Structured questionnaires were used to provide reliable results able to describe the relationship between study variables since they were set with Likert scale measurements from a scale of five ranging from strongly agree to strongly disagree. The collected results were filled in SPSS datasheet version 23.0 to generate statistics relevant to present primary data. With that, inferential statistics, specifically correlation and multiple regression analysis, were used to describe the relationship between study variables. On that note, the study is illustrated using the model stated as follows.

$\mathrm{CS}=\beta \mathrm{o}+\beta 1 \mathrm{LNC}+\beta 2 \mathrm{LIS}+\beta 3 \mathrm{LCR}+\mathrm{e}$

Where by $C S=$ Customer Satisfaction; $\beta o=$ Constant factor; $\beta 1 L N C=$ Limited Network Coverage; $\beta 2 L I S=$ Limited Internet Services; $\beta 3 L C R=$ Limited Customer Response; $e=$ Random variable 


\section{FINDINGS}

The findings were presented using inferential analysis to reveal the existing relationship between predicting variables of the study on the dependent variable. This is performed through correlation and multiple regression with model summary test shown first. This aims to indicate the entire influence of the predictors on the dependent variable, with table 1 illustrating the findings.

Table 1: Model Summary

\begin{tabular}{lllllllll}
\hline Model & $\mathbf{R}$ & $\begin{array}{l}\mathbf{R} \\
\text { square }\end{array}$ & $\begin{array}{l}\text { Adjusted } \\
\text { Square }\end{array}$ & $\begin{array}{l}\mathbf{R} \\
\text { Standard Error }\end{array}$ & $\begin{array}{l}\text { Change statistics } \\
\text { of Estimate }\end{array}$ & $\begin{array}{l}\text { Durbin- } \\
\text { Watson }\end{array}$ \\
\hline 1 & .718 & .617 & .603 & 49.054 & .506 & 68.038 & .000 & 1.514 \\
\hline
\end{tabular}

Dependent Variable: Customer Satisfaction

Independent Variables: Limited Network Coverage, Limited Internet Services, and Limited Customer Response

Table 1 indicates results on model summary test using the significant value of $\mathrm{R}^{2}$ revealing that customer satisfaction in public mobile service delivery is strongly affected with limited network coverage, limited internet services, and limited customer response by $61.7 \%$. The results imply that the predicting variables as study assumptions are positive and well attained for further analysis.

\section{Correlation Analysis}

The analysis is described to show the variable among the predicting ones with high influence than others to the dependent variable with table 2 illustrating the results.

Table 2: Correlation Analysis

\begin{tabular}{llllll}
\hline & & $\mathbf{1}$ & $\mathbf{2}$ & $\mathbf{3}$ & $\mathbf{4}$ \\
\hline 1. & Customer Satisfaction & 1 & & & \\
2. & Limited Network Coverage & 0.351 & 1 & & \\
3. & Limited Internet Services & 0.503 & 0.003 & 1 & 1 \\
4. & Limited Customer Response & 0.248 & 0.037 & 0.009 & 1 \\
\hline
\end{tabular}

Table 2 describes the results of correlation analysis which indicate that the limited internet services as the predicting variable correlate best than other predicting variables which are limited network coverage and limited customer response. This is the case because limited internet services as the predictor consist of a higher correlation value than the rest of the predicting variables. The implication is also that customer satisfaction in public mobile service delivery in Tanzania is mostly affected by

\section{Table 3: Multiple Regression Analysis}

limited internet services. Though the correlation is positive, the coefficient is small which signifies that there is no multicollinearity. The error is sorted through multiple regression.

\section{Multiple Regression Analysis}

The analysis is performed to show the contribution of each independent variable to the dependent variable with Table 3 illustrating the results.

\begin{tabular}{llllll}
\hline Model & \multicolumn{2}{l}{ Unstandardised Coefficients } & $\begin{array}{l}\text { Standardised } \\
\text { Coefficients }\end{array}$ & T & Sig. \\
\cline { 2 - 4 } & B & Std. error & Beta & \\
\hline (constant) & -9.838 & 3.267 & & -1.392 & .176 \\
Limited Network Coverage & 2.492 & .231 & .539 & 12.314 & .024 \\
Limited Internet Services & 2.274 & .208 & .562 & 12.629 & .017 \\
Limited Customer Response & 2.117 & .183 & .511 & 12.106 & .031 \\
\hline
\end{tabular}

26| This work is licensed under a Creative Commons Attribution 4.0 International License. 
Table 3 indicates results on multiple regression entailing that all three predicting variables, namely limited network coverage, limited internet services, and limited customer response are positive with significant effect statistically on customer satisfaction as the dependent variable with $\mathrm{p}<0.05$. The implication of the results is that customer satisfaction in public mobile service delivery in Tanzania is affected by limited network coverage, limited internet services, and limited customer response, respectively.

\section{DISCUSSION}

\section{Limited Network Coverage and Customer Satisfaction}

The study findings reveal that limited network coverage as the predictor is positive with a significant effect on customer satisfaction $(p<0.05)$. The implication of the results is that customer satisfaction in public mobile service delivery is affected by limited network coverage. This is acknowledged with TGC (2019) stating that public mobile services delivery in Tanzania is facilitated by one company. Services seem to possess some irregularities with network failure on an unexpected note being the common occurrence.

This has been affecting service delivery which constitutes implications with the competitive advantage attainment. Apart from that, Temba (2013) also suggest that public telecommunication company has engaged in competition with the existing private telecommunication companies in the market. However, network coverage is still a problem and shortcoming which affects service delivery. In that case, it has enabled many customers to possess limited trust and commitment in using the services than other service providers.

\section{Limited Internet Services and Customer Satisfaction}

The study findings show that limited internet services as the predictor is positive with a significant effect statistically on customer satisfaction with $\mathrm{p}<0.05$. The implication of the results is that customer satisfaction in public mobile service delivery is affected by limited internet services. The assertion is supported with Bujara
(2018) suggesting challenges the public telecommunication company faces in the performance of its duties that internet services are strong and efficient once available. However, with limited maintenance due to bureaucracies in the acquisition of equipment, once networks go down, they take time to be fixed which affects service delivery by the company.

In addition to that, Smith (2013) suggests that most telecommunication companies operating in Africa constitute limited internet services with public companies experiencing worse situations. This is attributed to the fact that the infrastructure to support the operations in a manner that may be effective and efficient is limited, which becomes a setback in the service delivery process and practice. This is the case with the local public telecommunication corporation in Tanzania that service delivery with regard to internet services is less reliable based on the consistency in the service availability and provision.

This is the situation because the facilities to provide such services such lines possess limited services sometimes with the situation persisting for quite a number of hours without any response. This distorts the satisfaction of customers because they are not always assured of the availability of internet services prior to their usage. This has resulted in most customers having alternative sources like other mobile service(s) from other company(s) to always facilitate the availability of internet services when one is in need.

\section{Limited Customer Response and Customer Satisfaction}

The study findings indicate that limited customer response as the predictor is positive with a significant effect on customer satisfaction with $\mathrm{p}<0.05$. The implication of the results is that customer satisfaction in public service delivery is affected by limited customer response. The claim is further supported by Bujara (2018) that among challenges employees encounter while delivering duties is the response of the customers on services delivered. This is the case because in most cases, they have been receiving more negative feedback than positive ones which have been devastating the practitioners. 
This is further acknowledged with Celebi (2015) that most public organisations which are different from private entities are that they lack avenues for customers and or consumers to express their views and needs. In fact, the perception of most people in the public realm is that public organisations consist of less supportive means to capture feedback from customers and act accordingly to satisfy customers. This has fostered many to have a negative perception with regard to the response of the public entities prior to customer needs and wants.

This is the case with Tanzania Telecommunication Corporation (TTCL) that as the public telecommunication company in the market with well-performing private sector entities competing; the allegiance in most cases is on the private entities because they have room for customer responses to be taken and considered useful inputs to be acted upon to improve the services provided to the consumers (Kalushekya, 2017).

\section{CONCLUSION AND RECOMMENDATIONS}

It is clear that public mobile service delivery in terms of customer satisfaction is affected by limited network coverage, limited internet services, and limited customer response. This is attributed to the fact that the variables have been found positive with a significant effect statistically on customer satisfaction. This is the reality because indeed, public mobile service delivery is still encountering severe shortcomings on networks and reliable internet services which are core functions in the mobile services in Tanzania to assure service quality. In that case, it is necessary for further measures to be undertaken to ensure that the situation is harmonised and combated to foster service quality provision to foster the performance of the organisation and market share generation through competitive advantage.

\section{Recommendations}

The paper recommends that the organisation should invest well in the equipment and facilities that assure effective and efficient network coverage. This is possible because the facilities and infrastructures for the company exist including in remote areas; all that is required is adequate maintenance measures. Once they are well focused automatically may surpass the private telecommunication companies in network coverage.

The paper also recommends that the company should work effectively in assuring that internet services are available at all times to the customers through the cell phones and other devices offered by the company. This is essential because it is the service that assures the competitive advantage which influences market share generation.

\section{Areas for Further Studies}

The study was conducted prior to customer satisfaction with regard to service quality in the public telecommunication industry. However, another study may be conducted on the same line with the focus on another unique industry such as the hospitality sector in hotels. Also, the study was conducted in line with causal relationship testing whereas another inquiry may be conducted using a qualitative approach.

\section{REFERENCES}

Bujara, I. (2018). The Influence of Organization Culture on Performance of Employees in Tanzania Telecommunication Company Limited (TTCL). DUP Publications.

Caruanaa, A., Ewing, M. T. and Ramaseshanc, B. (2000). Assessment of the Three-Column Format SERVQUAL: An Experimental Approach, Journal of Business Research, 49(1), $57-65$.

Celebi, S. I. (2015). How do motives affect attitudes and behaviors toward internet advertising and Facebook advertising? Computers in Human Behavior, 51, 312-324.

Dickson, Y. (2019). The Contribution of Advertisement on Customer Attractions in Mic Tigo Tanzania Company Limited. DUP Press.

Goldberg, S. (2016). Business Technical: Wearable Devices at Work. Business Insurance, 50(2), 116.

Harper, S. (2014). Economic and social implications of aging societies. Science, 346(6209), 587-591. 
Higgs, B., Polonsky M. J. and Hollick, M. (2005). Measuring Expectations: Pre and Post Consumption: Does It Matter? Journal of Retailing and Consumer Services, 12 (1).

Kalushekya, R. (2017). The Role of Monitoring and Evaluation on Sustainability of Construction Projects in Tanzania Telecommunication Company Limited. Gareth Stevens Publishers.

Khanna, V. S. (2013). The Economic History of the Corporate Form in Ancient India. London: Routledge.

Lee, F. L. (2016). Impact of social media on opinion polarisation in varying times. Communication and the Public, 1(1), 56-71.

Leigh, B. (2011). A Customer Service Makeover. Inc. Magazine.

Mahapatra, S. S. and Khan, M. S. (2006). A Methodology for Evaluation of Service Quality Using Neural Networks. Proceedings of the International Conference on Global Manufacturing and Innovation.

Nyangarika, A. (2016). An Analysis of Service Quality for Customer Satisfaction at Tanzania Posts Corporation. Journal of Marketing and Consumer Research, 20 (2016).

Ojasalo, J. (2010). E-service quality: a conceptual model. International Journal of Arts and Sciences, 3(7), 127-143.

Parasuraman, A., Zeithaml, V. A., \& Berry, L. (1988). SERVQUAL: A multiple-item scale for measuring consumer perceptions of service quality. 1988, 64(1), 12-40.

Parasuraman, A., Berry, L.L. and Zeithaml, V.A. (1985). Refinement and Reassessment of the SERVQUAL scale, Journal of Retailing, 67(4), 57-67.

Rowe, K. P. (2007). OSHA and small businesses: A winning combination: When small businesses tap into OSHA's many resources, everyone benefits. Occupational Hazards, 69(3), 33-49.
Shanka, M. S. (2012). Measuring service quality in Ethiopian airlines. Journal of Educational and Social Research, 2(9), 173-173.

Siria, W. (2018). Effect of Corporate Social Responsibility on the Corporate Performance in Telecommunication Companies in Tanzania. Gareth Stevens Publishers.

Skinner, B. F. (2015). Cumulative record: Definitive edition (Vol. 4). BF Skinner Foundation.

Smith, A. (2013). History of the East African posts and telecommunications administration 1837 to 1967. Routledge.

Swallehe, O. (2021). Service Delivery and Customer Satisfaction in Public Organizations. IUP Journal of Marketing Management, 20(2), 7-33.

Swallehe, O., \& Mandari, U. (2013). Management of Library Quality Services in Public Universities in Tanzania. Anvesha, 6(4).

Temba, M. (2013). The assessment of service quality and customer satisfaction using SERVQUAL Model: The Case Study of Tanzania Telecommunications Company Limited (TTCL) (Doctoral dissertation, The Open University of Tanzania)

TGC (2019). SaskTel Pulls Out of TTCL Deal. Telegeography.

Tripathy, D. \& Goma, E. (2010). Bharti closes the \$9 billion Zain Africa deal. Reuters. https://www.reuters.com/article/us-zain-bhartiidUSTRE6570VJ20100608

Uysal, H. T. \& Mehmet, S. Y. (2013). Effect of Organizational Levels on Individual Service Quality in Health Service: A Research on Doctors. İktisatíşletmeveFinansDergisi. 28(329), pp.21-48.

Veblen, T. (1904). The Theory of the Business Enterprise. New Brunswick, New Jersey: Transaction Books.

Wolfinbarger, M. \& Gilly, M. C. (2013). eTailQ: Dimensionalizing, Measuring and Predicting

$29 \mid$ This work is licensed under a Creative Commons Attribution 4.0 International License. 
Etail Quality, Journal of Retailing 79 (3), 18398.

Zeithaml, V., Parasuraman, A. and Berry, L. L. (1990). Delivering Service Quality: Balancing Customer Perceptions and Expectations. Free Press.

Zwick, R., Pieters, R., \& Baumgartner, H. (1995). On the practical significance of hindsight bias: The case of the expectancy-disconfirmation model of consumer satisfaction. Organisational behavior and human decision processes, 64(1), 103-117. 